\title{
HISTOPATOLOGI HEPAR TIKUS PUTIH (Rattus Novergicus) YANG DIINDUKSI DENGAN PARASETAMOL DOSIS TOKSIK PASCA PEMBERIAN EKSTRAK ETANOL DAUN KELOR (Moringa Oleifera)
}

\author{
Noer Kumala Indahsari \\ Departemen Biokimia, Fakultas Kedokteran \\ Univesitas Wijaya Kusuma Surabaya \\ email: noerkumala04176@gmail.com
}

Received 16 Oktober 2017

Accepted 28 Nopember 2017

\begin{abstract}
Abstrak
Hepar tempat utama metabolisme obat yang disebut juga sebagai biotransformasi dan hasil akhir dari reaksi ini berupa substansi yang tidak aktif dan lebih larut dalam air, sehingga cepat diekskresi melalui empedu dan urin. Setiap gangguan hati dapat menghambat fungsi normal tubuh. Kerusakan sel-sel hepar dapat disebabkan antara lain oleh obat, virus, dan berbagai senyawa kimia lain mempunyai daya hepatotoksik, antara lain adalah parasetamol.Penelitian ini menggunakan 5 kelompok Tikus Putih (masing-masing kelompok 5 ekor tikus) yang diinduksi parasetamol dosis toksik kemudian diberikan ekstrak Etanol Daun Kelor (Moringa Oleifera) dengan dosis 250mg/200BB, 500mg/200 BB, dan 1000mg/200BB selama 7 hari untuk kelompok P1, P2 dan P3 sedangkan kelompok Kontrol positif hanya diberi pakan dan minum biasa, serta kelompok control negatif hanya diberikan parasetamol dosis toksik saja. Hasil penelitian menunjukkan bahwa kelompok perlakuan P3 dengan pemberian ekstrk etanol dosis tinggi yaitu $1000 \mathrm{mg} / 200 \mathrm{BB}$ dapat melindungi hepar tikus yang telah diinduksi dengan parasetamol dosis toksik, hal ini dapat dibuktikan dengan melihat gambaran histopatologi hepar tikus yang mengalami pengurangan baik dari sisi peradangan, nekrosis maupun degenerasi.
\end{abstract}

Katakunci: parasetamol, ekstrak etanol daun kelor, gambaran histopatologi hepar

\begin{abstract}
Hepar the main place of drug metabolism is also referred to as biotransformation and the end result of this reaction is inactive substance and more soluble in water, so quickly excreted through bile and urine. Any liver disorder can inhibit the normal functioning of the body. Damage to hepatic cells can be caused among others by drugs, viruses, and various other chemical compounds have hepatotoxic power, such as paracetamol. This research uses 5 groups of White Rats (each group 5 rats) induced paracetamol toxic dose and then given the extract of Etanol Leaves Kelor (Moringa Oleifera) with dose 250mg / 200BB, 500mg / 200BB and 1000mg / 200BB for 7 days for group P1, P2 and P3 while the positive control group was given only regular feed and drink, and the negative control group was given only toxic doses of paracetamol. The results showed that P3 treatment group with high dose ethanol extract of $1000 \mathrm{mg} / 200 \mathrm{BW}$ can protect the induced mouse liver with toxic doses of paracetamol, this can be proved by looking at the histopathologic picture of liver of mice that experienced a good reduction in inflammation, necrosis or degeneration.
\end{abstract}

Keywords: paracetamol, leaf moringa ethanol extract, histopathology hepar figure. 


\section{Pendahuluan}

Pusat metabolisme tubuh yang mempunyai fungsi sangat kompleks dan menempati sebagian besar kuadran kanan atas abnomen adalah Hepar. Hepar tempat utama metabolisme obat yang disebut juga sebagai biotransformasi dan hasil akhir dari reaksi ini berupa substansi yang tidak aktif dan lebih larut dalam air, sehingga cepat diekskresi melalui empedu dan urin. Setiap gangguan hati dapat menghambat fungsi normal tubuh. Kerusakan sel-sel hepar dapat disebabkan antara lain oleh obat, virus, dan berbagai senyawa kimia lain mempunyai daya hepatotoksik, antara lain adalah parasetamol (Puspitasari, 2010).

Penggunaan parasetamol secara berlebihan atau melebihi dosis dapat mengakibatkan kerusakan hati. Ikawati, 2010 menjelaskan bahwa kerusakan hepar oleh parasetamol secara berlebihan disebabkan karena terbentuknya metabolit reaktif toksik ( $\mathrm{N}$-asetil-p-benzoquinon) dan radikal bebas melaui proses biotrnaformasi oleh enzim sitokrom P450 dengan bantuan isoenzim CYP2EI. Metabolit reaktif toksik dan radikal bebas dapat mengganggu integritas membran sel dan berlanjut menjadi kerusakan hepar selanjutnya gagal ginjal. Overdosis parasetamol dapat terjadi pada penggunaan akut maupun berulang. Hepatotoksisitas akan terjadi pada penggunaan 7,5-10 gram dalam waktu 8 jam atau kurang. Kematian bisa terjadi jika parasetamol digunakan samapi 15 gram

Penumpukan radikal bebas merupakan salah satu mekanisme yang berperan terhadap kerusakan hepar. Radikal bebas yang berlebihan akan menimbulkan stress oksidatif yang memicu proses peroksidasi terhadap lipid, sehingga menimbulkan penyakit kanker, inflamasi, ateroklerosis, dan mempercepat proses penuaan (Koch et al., 2007). Malondialdehid (MDA) merupakan senyawa yang digunakan sebagai penanda terjadinya stress oksidatif,dan sebagai produk oksidasi asam lemak tidak jenuh oleh radikal bebas serta metabolit komponen sel yang dihasilkan oleh radikal bebas. Tingginya kadar MDA menunjukkan adanya proses oksidasi dalam membrane sel, bila antioksidan tinggi biasanya diikuti oleh penurunan kadar MDA (Ramatina, 2011)

Sehingga untuk menghindari efek samping pemberian parasetamol dosis toksis sangat diperlukan, dengan cara memberikan hepatoprotektan yang dapat melindungi hati. Salah satu bahan alami yang berfungsi sebagai hepatoprotektor adalah ekstrak etanol daun kelor. Daun Kelor merupakan tanaman yang mengandung senyawa-senyawa kimia yang bermanfaat, diantaranya adalah senyawa flavonoid. Keberadaan senyawa flavonoid inilah yang dapat menangkap radikal bebas penyebab kerusakan hepar (Tagliaferro, et al., 2002). Hampir semua bagian dari tanaman daun kelor dapat dijadikan bahan antimikroba (Bukar et al,2010). Manfaat lain dari daun kelor diantaranya sebagai anti anemia (Oduro et al., 2008), penurunan tekanan darah tinggi dan obat diabetes (Giridhari et al.,2011), serta sebagai obat radang usus besar (Fugli,1999). Daun kelor digunakan juga sebagai obat menurunkan kolestrol, diare, disentri, colitis, gonorhea,sakit kepala, anemia, iritasi, infeksi, antialergi, antikarsinogenik, antihelminthes dan anti inflamasi (Faizi,1995; Karr,2003; Guevara,1999)

\section{Metode Penelitian \\ Alat dan Bahan}

Evaporator, alat sonde, papan paraffin, saringan Tip top, tissue Cassette, paraffin jar, microtom, mikroskop, Etanol 96\% aquades, parasetamol, Daun Kelor, pakan tikus 511, reagen MDA, larutan PBS, larutan TCA 15\%, Larutan TBA 0,37\%, kloroform, buffer formalin, hepar tikus,

\section{Preparasi Hewan Coba}

Hewan Coba tikus putih galur wistar sebanyak 25 ekor dengan berat 200-300 gram. Hewan coba yang terkumpul diadaptasi selama satu minggu (diberi 
pakan biasa dan akuades).Hewan coba yang telah diadaptasi satu minggu dikelompokkan secara acak menjadi 5 kelompok.

\section{Preparasi Ekstrak Etanol Daun Kelor}

Daun kelor dicuci dan dikeringkan 2-4 hari, lalu diblender. Kemudian dihaluskan dan ditimbang $1 \mathrm{~kg}$ dimaserasi dengan etanol $70 \%$ selama 24 jam dan disaring. Rresidu dimaserasi lagi sampai filtrat jernih. Filtrat/maserat dikumpulkan jadi satu, dipekatkan dengan vacuum evaporator (suhu $30-40^{\circ} \mathrm{C}$, tekanan $75 \mathrm{mmHg})$.

\section{Perlakuan terhadap hewan coba}

a. Kelompok Kontrol Positif hanya diberi pakan biasa dan aquadest selama 14 hari

b. Kelompok Kontrol negatif diberi aquadest selama 10 hari+ parasetamol 2gr/200BB tikus pada hari ke 7

c. Kelompok P1 diberi ekstrak etanol daun kelor 250mg/200BB tikus selama 14 hari+parasetamol 2gr/200BBtikus pada hari ke 7

d. Kelompok P2 diberi ekstrak etanol daun kelor 500mg/200BB tikus selama 14 hari+parasetamol 2gr/200BB tikus pada hari ke 7

e. Kelompok P3 diberi ekstrak etanol daun kelor 1000mg/200BB tikus selama 14 hari+parasetamol $2 \mathrm{gr} / 200 \mathrm{BB}$ tikus pada hari ke 7

\section{Pengambilan hepar hewan coba}

Pengambilan hepar hewan coba pada semua kelompok dilakukan setelah proses terminasi tikus dengan pembedahan.

\section{Proses Penyondean Tikus}

Untuk memasukkan dosis ekstrak daun kelor dan dosis parasetamol pada tikus putih dilakukan penyondean agar semua perlakuan dipastikan bisa masuk. Berikut langkah-langkah melakukan penyondean pada tikus putih:

1. Sebelum perlakuan harus diperhatikan dan dipastikan bahwa semua kelompok tikus sudah diberi pakan dan minum, kemudian setian satu minggu sekali alas tikus atau sekam harus diganti dan kandang dibersihkan dari kotorannya.

2. Tikus putih dipegang dengan tangan kiri, bagian kepalanya dijepit dengan jari tengah dan jari manis. Dalam hal ini tangan harus dilindungi dengan sarung tangan supaya aman dari gigitan tikus dan bahaya penyakit lainnya.

3. Kemudian posisi tikus dibalikkan sehingga telentang dengan posisi kedua jari tetap menjepit kepala tikus.

4. Tikus putih Kelompok P1A,P1B, P2A, P2B , P3A dan P3B diberi perlakuan larutan ekstrak daun kelor sesuai dengan dosis yang sudah ditentukan

5. Kemudian selang waktu 2 jam tikus putih PIA,PIB, P2A, P2B , P3A dan P3B diberi perlakuan larutan parasetamol dengan dosis yang sudah ditentukan.

6. Tikus putih yang tanpa perlakuan yaitu kelompok kontrol negatif hanya diberi perlakuan larutan parasetamol saja

7. Tikus putih kelompok control positif hanya diberi pakan dan aquadest tanpa pemberian ekstrak daun kelor maupun parasetamol.

Pengamatan Histopatologi Hepar Tikus. Organ hepar dibuat preparat histopatologi dengan pewarnaan Hematoksilin-Eosin. Kemudian preparat histopatologi dikirim ke laboratorium Patologi Anatomi untuk dikonsultasikan dengan ahli patologi anatomi.Pengamatan mikroskopis dilakukan oleh peneliti sendiri.

\section{Hasil dan pembahasan \\ Ekstraksi Daun Kelor}

Daun Kelor yang telah dicuci, dikeringkan dengan cara diangin-anginkan selama 2-4 hari untuk menghindari rusaknya kandungan flavonoid yang ada didalam daun kelor. Untuk mendapatkan hasil yang benar-benar kering ternyata 
membutuhkan waktu 5 hari. Untuk mendapatkan hasil daun kelor kering sebanyak $1 \mathrm{~kg}$ membutuhkan lebih dari 3 $\mathrm{kg}$ daun kelor basah. Didapatkan 763 gr serbuk daun kelor yang selanjutnya dievaporasi menjadi filtrat etanol daun kelor dan dari hasil evaporasi didapatkan $3.950 \mathrm{~mL}$ filtrate hasil evaporasi yang setelah dipekatkan didapat hasil ekstrak etanol daun kelor sebanyak 113 gram untuk digunakan sebagai terapi hepar yang diinduksi parasetamol dosis toksis.

\section{Analisis Hasil Gambaran Histopatologi Hepar Tikus}

Menurut Chyka PA, 2006, Sel hepatosit secara makroskopis mempunyai inti bulat, sitoplasma jernih dan tersusun sistematis membentuk lempengan radier ke arah lobules pusat (vena sentralis). Jika sel hepar terinduksi parasetamol dosis toksik maka sel hepar dapat mengalami cedera melalui beberapa proses stress oksidatif akibat menumpuknya metabolit NAPQ1
(N-Acetyl p-benzoquinone) yang merusak mitrokondria dan menghambat pembentukan energy sel hepatosit. Tanda kerusakan hati yang diakibatkan oleh parasetamol di antaranya adalah menurunnya jumlah protein total maupun glikogen. Hal itu terjadi karena berkurangnya jumlah sel hepatosit yang memproduksi protein dan glikogen sehingga berat organ hati secara keseluruhan lebih kecil dari berat normalnya. Indikasi kelainan hati antara lain adanya cloudy swelling (degenrasi butir) merupakan indikasi awal terjadinya nekrosis, nekrosis dimana inti sel hilang, degenerasi, dan infiltrasi lemak.

Pada penelitian ini preparat kelompok kontrol menunjukkan adanya banyak sel Kupfer daripada radang, degenerasi sangat sedikit sehingga bisa disimpulkan bahwa kelompok kontrol dianggap masih dalam kondisi normal, hal ini bisa ditunjukkan pada gambar 1 .

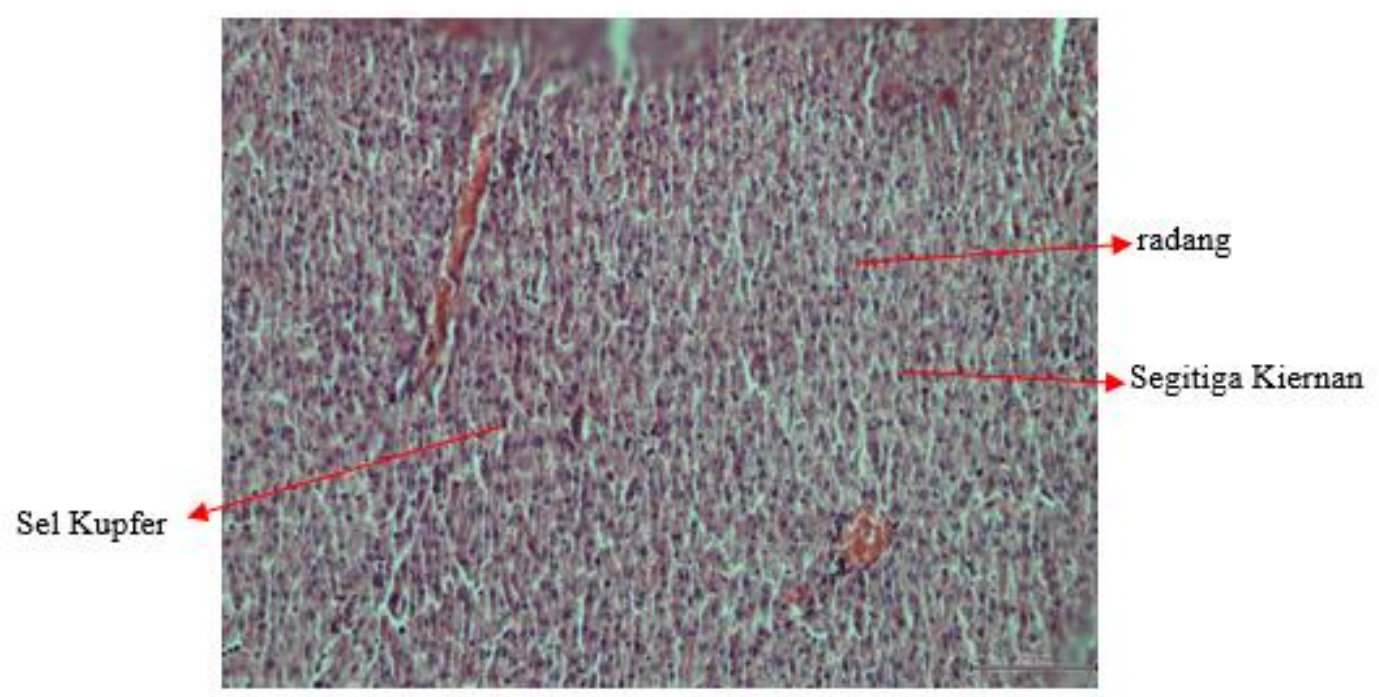

Gambar 1. Sel hepatosit dengan perbesaran 10x, kelompok kontrol Positif, ada radang tetapi lebih banyak sel Kupfer, degenerasi tidak ada, nekrosis tidak ada.

Jika dibandingkan dengan kelompok kontrol negatif yang diberi parasetamol saja maka peradangan lebih banyak bahkan terkumpul diluar segitiga Kiernan, dan ada banyak nekrosis, hal ini bisa ditunjukkan gambar 2 


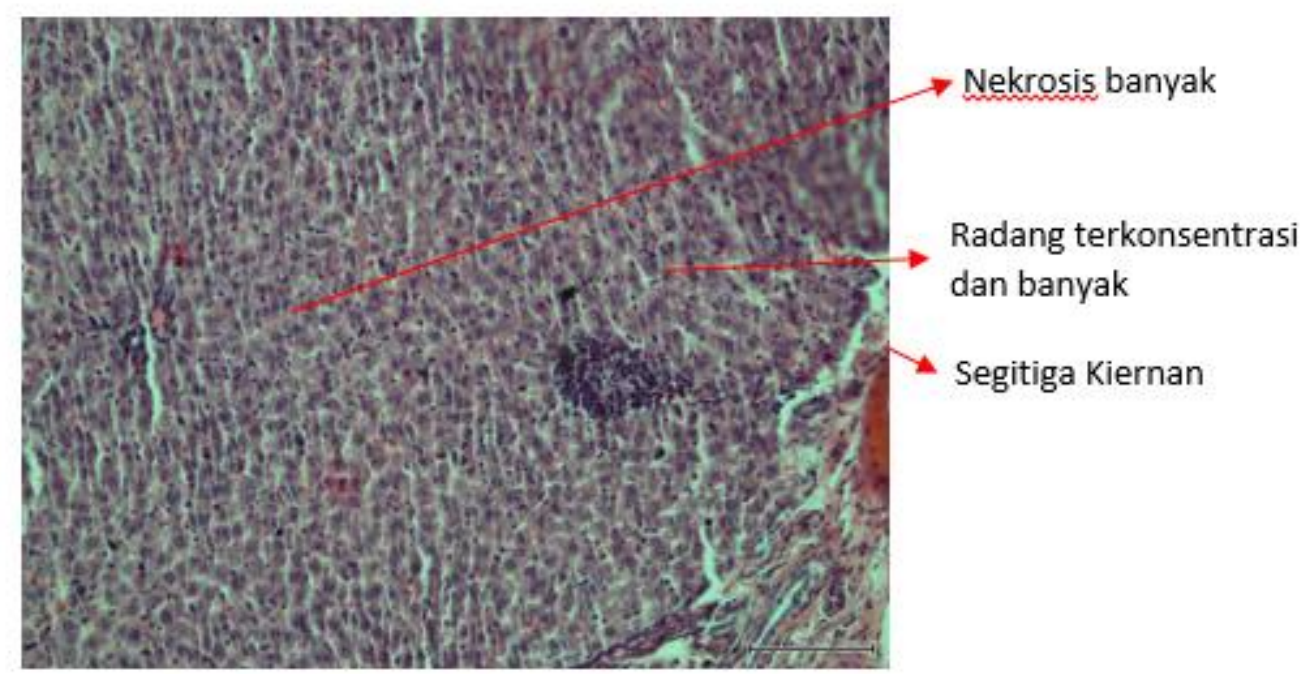

Gambar 2. Sel Hepatosit kelompok Kontrol Negatif (merupakan kelompok yang hanya diberi parasetamol dosis toksik saja tanpa ada treatment pengobatan), menunjukkan ada radang yang banyak dan banyak nekrosis.

Pada gambar 2 merupakan Kelompok kontrol negative yang merupakan kelompok yang hanya diberi parasetamol dosis toksik saja tanpa adanya perlakuan perlindungan hepar tikus dengan ekstrak daun kelor menunjukkan bahwa ada peradangan yang banyak (bintik-bintik hitam yang tersebar dan terkonsentrasi pada sekitar dan dekat segitiga Kiernan, dan ada banyak nekrosis ( sel yang kehilangan intinya, terlihat dari tengah inti yang kosong), membuktikan bahwa parasetamol dapat mencederai hepar tikus.

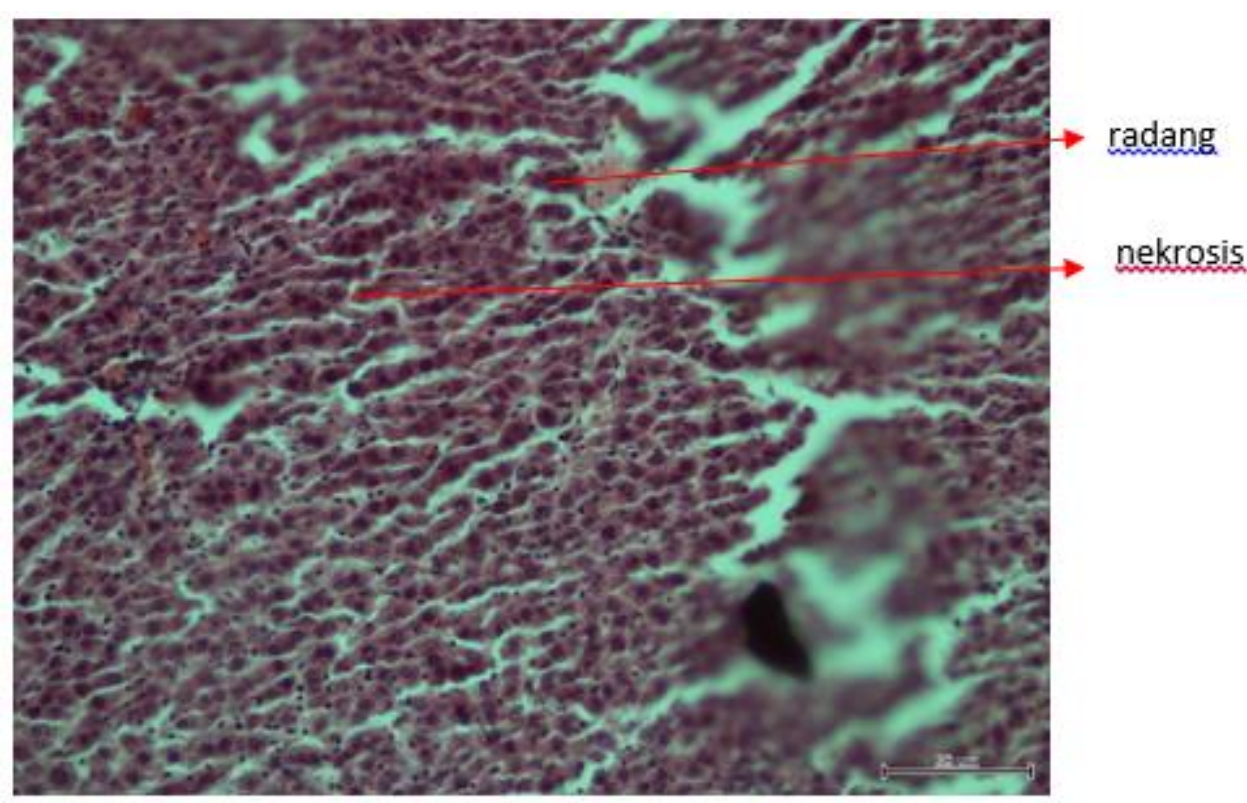

Gambar 3. Sel Hepatosit perbesaran 20X pada kelompok P1 (kelompok tikus dengan perlakuan dosis ekstrak Daun Kelor rendah yaitu $250 \mathrm{mg} / 200 \mathrm{~g} \mathrm{BB}$ dan Parasetamol dosis toksik), terlihat ada banyak radang, ada degenerasi dan nekrosis. 
Pada gambar 3, Kelompok P1 yaitu kelompok tikus dengan perlakuan ekstrak daun Kelor dosis $250 \mathrm{mg} / 200 \mathrm{~g}$ BB ditambah dengan pemberian parasetamol dosis toksis, menujukkan bahwa masih terdapat peradangan, degenerasi dan nekrosis namun tidak sebanyak kelompok control negative pada gambar 2 .

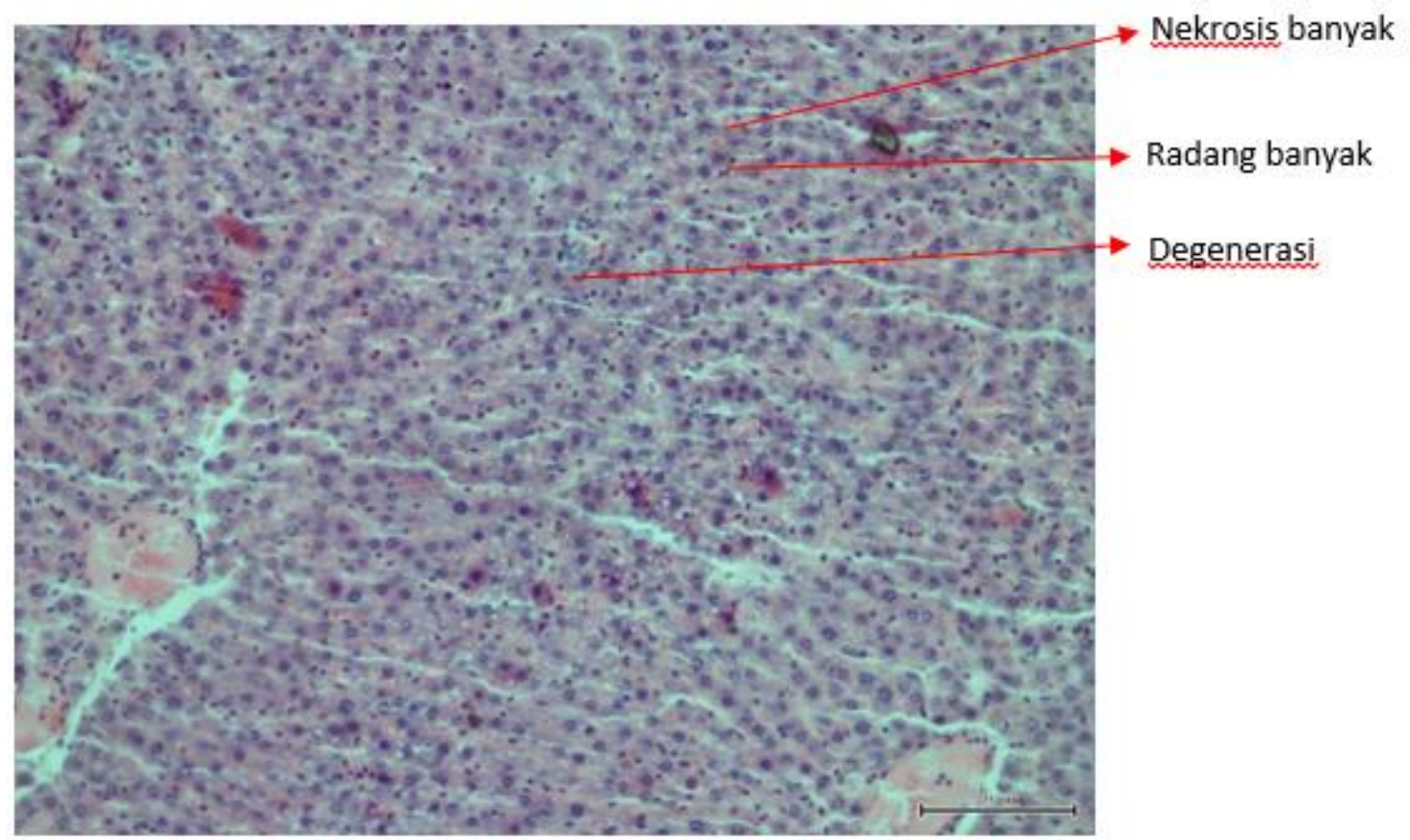

Gambar 4. Sel Hepatosit Kelompok P2 (kelompok tikus dengan perlakuan dosis ekstrak Daun Kelor sedang yaitu $500 \mathrm{mg} / 200 \mathrm{~g}$ BB dan Parasetamol dosis toksik), ada banyak nekrosis, radang, ada degenerasi.

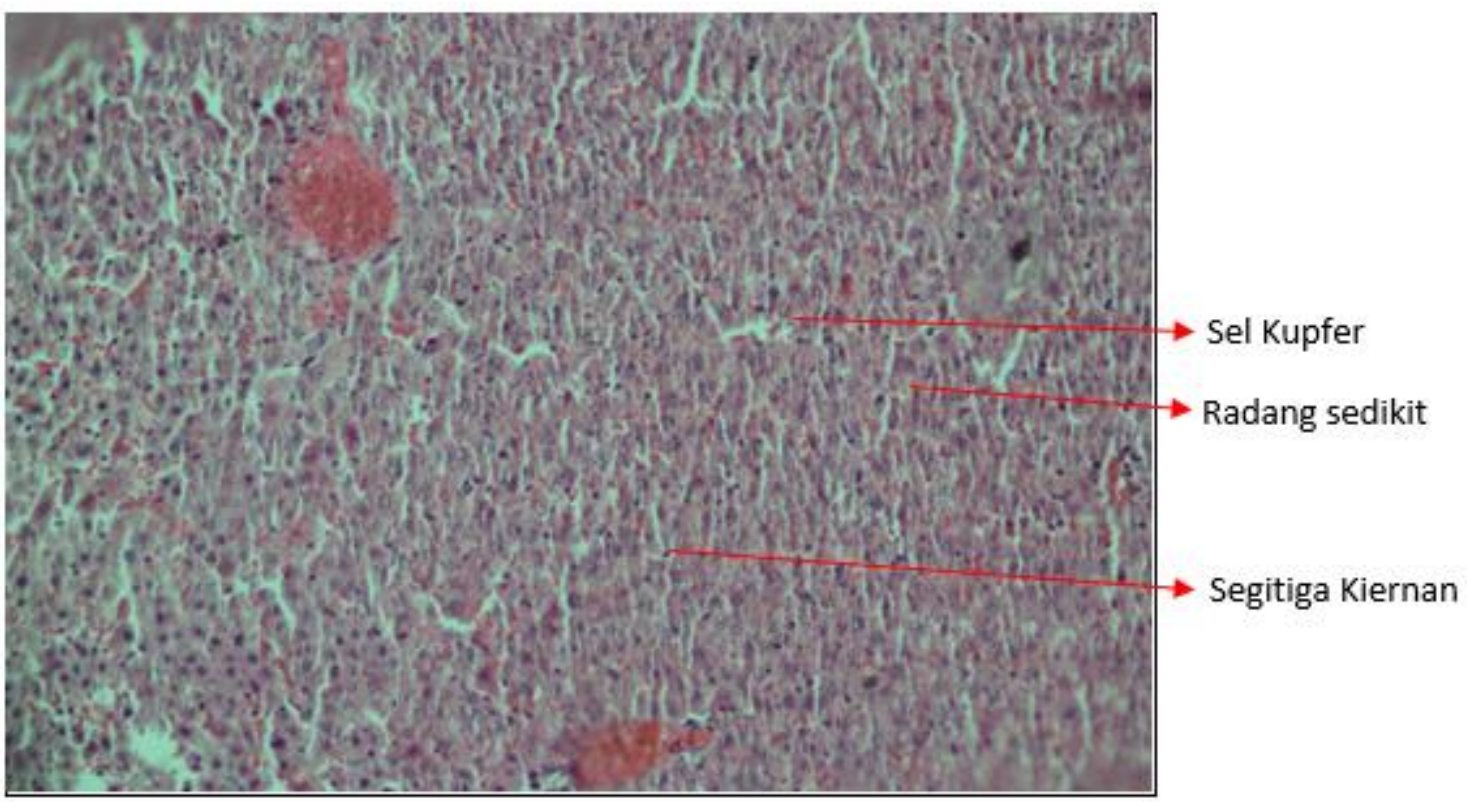

Gambar 5. Sel Hepatosit perbesaran $10 \times$, untuk kelompok P3 (kelompok tikus dengan perlakuan dosis ekstrak Daun Kelor tinggi yaitu 1000 mg/200 g BB dan Parasetamol dosis toksik), ada radang tapi lebih banyak sel Kupfer, nekrosis berkurang, hampir sama dengan kelompok Kontrol positif. 
Pada gambar 4, Kelompok P2 yaitu kelompok tikus dengan pemberian perlakuan dosis ekstrak daun kelor dosis sedang yaitu $500 \mathrm{mg} / 200 \mathrm{gBB}$ dan parasetamol dosis toksik menunjukkan bahwa ada banyak peradangan, nekrosis dan degenerasi namun tidak sebanyak kelompok kontrol negatif. Hal tersebut juga membuktikan bahwa adanya pemberian ekstrak daun kelor dapat menurunkan cedera yang diakibatkan zat toksik seperti parasetamol dosis toksis jika dibandingkan dengan kondisi hepar tikus ketika hanya diberi parasetamol saja.

Pada gambar 5, kelompok P3 yaitu kelompok tikus dengan pemberian perlakuan ekstrak daun kelor dosis tinggi, $1000 \mathrm{mg} / 200 \mathrm{gBB}$ dan parasetamol dosis toksis, menunjukkan bahwa ada penurunan yang signifikan karena jumlah radang semakin sedikit dan lebih banyak sel Kuppfer ( sel Kupfer banyak dijumpai di sel hepatosit yang normal), jumlah nekrosis juga berkurang sehingga kondisi sel hepar hamper sama dengan sel hepar yang normal, berarti hal tersebut dapat membuktikan bahwa pemberian ekstrak daun kelor dosis $1000 \mathrm{mg} / 200 \mathrm{~g} \mathrm{BB}$ dapat melindungi hepar tikus
Kondisi normal hepar peradangan seringkali ada, tetapi tidak banyak. Jika ada senyawa toksik yang dapat meracuni hepar, maka jumlah peradangan semakin banyak, disamping ada nekrosis serta degenerasi sel hepar. Dengan membandingkan gambaran Histopatologi hepar tikus dapat disimpulkan bahwa dosis ekstrak Etanol Daun Kelor dengan dosis tinggi yaitu $1000 \mathrm{mg} / 200 \mathrm{gr} \mathrm{BB}$ dapat memperbaiki kondisi hepar tikus yang diberi parasetamol dosis toksis. Hal ini dapat di buktikan dengan adanya penurunan jumlah peradangan dan penurunan nekrosis jika dibandingkan dengan gambaran histopatologi kelompok kontrol negatif. Berntuk gambaran histopatologi hepar Tikus kelompok perlakuan dengan pemberian ekstrak Daun kelor dosis tinggi hampir sama dengan gambaran histopatologi kelompok kontrol positif yang normal.Sedangkan untuk pemberian ekstrak daun kelor untuk dosis rendah dan sedang belum memberikan perbaikan yang bermakna terhadap pengaruh pemberian parasetamol dosis toksik akan tetapi dapat menurunkan nekrosis daripada kelompok kontrol negatif.

Tabel 1. Data Kondisi Hepar Tikus

\begin{tabular}{llllll}
\hline $\begin{array}{l}\text { Kondisi } \\
\text { Hepar }\end{array}$ & $\begin{array}{l}\text { Kontrol } \\
\text { Positif }\end{array}$ & $\begin{array}{l}\text { Kontrol } \\
\text { negatif }\end{array}$ & P1 & P2 & P3 \\
\hline Radang & + & +++ & + & + & + \\
Nekrosis & - & +++ & ++ & ++ & + (sedikit) \\
Degenerasi & - & + & + & ++ & + (sedikit) \\
\hline
\end{tabular}

\section{Kesimpulan}

Berdasarkan penelitian yang telah dilakukan terhadap gambaran histopatologi hepar Tikus Putih yang diinduksi dengan parasetamol dosis toksik pasca pemberian ekstrak etanol daun Kelor dapat dibuktikan bahwa dosis pemberian ekstrak etanol daun kelor sebesar $1000 \mathrm{mg} /$ 200 BB bisa memperbaiki kondisi hepar Tikus Putih yang telah rusak karena diinduksi parasetamol dosis toksik. 


\section{Daftar Pustaka}

Bukar,A., Uba,A. And Oyeyi, T.I. 2010. Antimicrobial Profile of Moringa oleifera Lan. Extracts Agains Some Food-Bornr Microorganisms. Bayero Journalof Pure and Applied Sciences, 3(1): 43-48.

Chyka PA, et al, 2006, Acetaminophen Poisoning, an Evidence Based, Consensus Guideline for Out of Hospital Management, Clinical Toxicology ; 44(1):1-18

Faizi S. Siddiqui BS. Saleem R. 1995. Fully Acetylared Carbamate and Hypotensive Thiocarbonated Glycosidea From Moringa Oleifera. J. Phytochemistry.38:957-963.

Giridhari, V.V A., D. Malathi., K. Geetha. 2011. Anti Diabetic Property of Drumstick (Moringa oleifera) Leaf Tablets. Int J Health Nutr 2011 2(1):15.

Guevara Ap. Vargas C, Sakurai H et al. 1999. An Antitumor Promoter from Moringa Oleifera Lam.Muttat Res. 440:181-188

Hardman Joel G.2007. Goodman and Gilman Dasar Farmakologi Terapi. Jakarta:EGC

Ikawati Zullies.2010.Cerdas Mengenali Obat. Yogyakarta.Kanisiuss.

Karr A, Choudhry BK. Bandyopadhyay NG. 2003. Comparative Evaluation of Hypoglycaemic Activity of Some Indian Medical Plants in Allxan Diabetics Rats. J. Ethnopharmacol 84:105-108
Koch, D dan Jeratnam, 2009, Buku Ajar dan Praktik Kedokteran Kerja, Jakarta:EGC.

Makkar, Becker K.1997. Nutrients and Antiquality Factors in Different Morfphological Parts of The Moringa Oleifera Tree, J Agric Sci, Cambridge. 128:311-322

Murugesh, K.S., et al, 2005, Hepatoprotective and antioxidant role of Berbens Tinctona Lasch Leaves on Parasetamol induced Hepatic Damage in Rats, Iranian, J. Pharmacol Therapeutic (IJPT) 4(1): 64-69

Oduro, I., W. O. Ellis and D. Owusu. 2008. Nutritional potential of two leafy vegetables: Moringa oleifera and Ipomoea batatas leaves. Scientific Research and Essy Vol.3(2),pp.057060.

Puspitasari ika.2010. Jadi Dokter Untuk Diri Sendiri. Yogyakarta:B First.

Ramatina.2011. Efektifitas Berbagai Suplemen Antioksidan Terhadap Penurunan Status Oksidatif Malondialdehyd (MDA Plasma) Pada Mahasiswa Alih jenis Ipb.Skripsi.Institut Pertanian Bogor.Bogor

Roloff, A., H. Weisgerber., U. Lang., B. Stimm. 2009. Moringga oleifera LAM., 1785. WILEY-VCH Verlag GmbH \& Co. KgaA, Weinheim.

Tagliaferro, A.R., et all., 2002, Flavonoid Antioxidants: Chemistry, Metabolismand Structure activity Relationship, Journal of Nutritional Biochemistry, 13:572-584 